\title{
COURTING CONTROVERSY: THE PROBLEMS CAUSED BY EXTRAJUDICIAL SPEECH AND WRITING
}

\author{
Jasmin Moran*
}

This article explores the problems for judicial impartiality that a judge's extrajudicial speaking or writing on legal matters may create. Examples from New Zealand and abroad demonstrate such extrajudicial commentary may lead to a finding of apparent bias or require that a judge recuse him or herself from hearing a case. The current regulation of extrajudicial speech, as ascertained from judicial conduct codes and case law, provides that judges can speak and write extrajudicially but must exercise caution in the tone and language they use. The article concludes that this is an appropriate approach and that the alternative of judicial silence is undesirable.

\section{INTRODUCTION}

In 2012, when Judge David Harvey spoke at the NetHui conference on internet law months before he was due to hear Kim Dotcom's extradition hearing, no one expressed concern. This is largely because the practice of judges writing or speaking extrajudicially is common in New Zealand and seen as largely innocuous. However, when, in the course of his speech, Judge Harvey joked that the United States was the "enemy", it led to a media furore. In those circumstances, the Judge chose to recuse himself from hearing the case. This example demonstrates that extrajudicial commentary, while it may appear benign, can have serious consequences. Specifically, such commentary may be the basis of a determination that a judge is biased or may necessitate recusal. The purpose of this article is to explore this problem.

As background to the issue, Part II discusses the concept of judicial impartiality and why it is demanded. It also explains the law relating to judicial bias and recusal. Part III then examines the specific bias and recusal issues that extrajudicial speech creates. This includes a discussion of empirical research conducted by the author on the extent of judicial publication in New Zealand law

* Submitted as part of the LLB(Hons) programme at Victoria University of Wellington. 
reviews. ${ }^{1}$ In addition, the Part will provide further detail on the incident involving Judge Harvey as well as examples from England, Scotland and the United States. Next, Part IV explains how extrajudicial speech is regulated, as identified in judicial conduct codes and case law. Broadly, the current position is that extrajudicial speech is permissible, but judges must consider the tone and language they employ. If a judge is too immoderate in his writing or speaking, this may lead to a finding of apparent bias or require recusal.

Having ascertained the current rules surrounding extrajudicial speech, the remainder of the article is dedicated to determining whether this approach is favourable. Part V explores the policy goals that underpin any approach to extrajudicial speech: protecting judicial free speech and ensuring the judicial system functions effectively and efficiently. With these competing interests in mind, Part V discusses whether the status quo achieves an appropriate balance. A reform option of judicial silence, proposed by Australian academics, Bartie and Gava, ${ }^{2}$ is considered in Part VI.

The conclusion reached is that the current regulation of extrajudicial speech, which focuses on the particular tone and language a judge has used, is correct. This approach provides for a judge's right to freedom of expression, while also ensuring that the functioning of the legal system is unharmed. As such, there is no imperative for reform. Bartie and Gava's suggestion of judicial silence is rejected on this basis, and also because it would produce undesirable results. As a critique, Part VII concludes by considering a legal realist perspective, which interprets extrajudicial speech in a very different manner.

\section{JUDICIAL IMPARTIALITY}

The judicial system is founded on the values of independence and impartiality. Judicial independence is the notion that the judiciary is not beholden to the executive and legislature, and that judges are independent from their colleagues and the parties. ${ }^{3}$ The New Zealand Guidelines on Judicial Conduct (Guidelines) describes judicial independence as a "means to the end of impartiality". ${ }^{4}$ Judicial impartiality encompasses rights of natural justice, specifically the well-known Latin maxims of nemo iudex in causa sua and audi alteram partem. ${ }^{5}$ This article concentrates on judicial impartiality and argues it may be called into question by a judge's extrajudicial writing. As such, this Part explores the concept of judicial impartiality and its importance.

1 The findings of this research are summarised in the Appendices to the article.

2 Susan Bartie and John Gava "Some Problems with Extrajudicial Writing" (2012) 34 Syd L Rev 637.

3 Shimon Shetreet "Judicial independence and accountability: core values in liberal democracies" in HP Lee (ed) Judiciaries in Comparative Perspective (Cambridge University Press, Cambridge, 2011) 3 at 3.

4 "Guidelines for Judicial Conduct" (March 2013) Courts of New Zealand <www.courtsofnz.govt.nz> at [27].

5 Translation: "no one be a judge in their own case" and "one must listen to both sides". See Brian Flanagan "Scalia, Hamdan and the Principles of Subject Matter Recusal" (2007) 19 Denning LJ 149 at 149. 


\section{A What is Impartiality?}

Impartiality is the "essential" attribute of a judge. ${ }^{6}$ Ipp $^{7}$ describes the judiciary as "conditioned to believe that to act other than impartially is essentially evil and inimical to" their "code of conduct". ${ }^{8}$ To act impartially requires that the judge's sole motivation in judging is to "do right according to the law to the parties". 9 Judicial impartiality is enshrined in the judicial oath to "do right to all manner of people after the laws and usages of New Zealand without fear or favour, affection or ill will". 10 Restating this in contemporary language, Lord Bingham has noted the oath requires: ${ }^{11}$

That a judge must free himself of prejudice and partiality and so conduct himself, in court and out of it, as to give no ground for doubting his ability and willingness to decide cases coming before him solely on their legal and factual merits as they appear to him in the exercise of an objective, independent and impartial judgment.

It is recognised that a judge's impartiality must exist in fact and by reasonable appearance. ${ }^{12}$ In the words of Lord Hewart's famous maxim, "justice must not only be done, but should manifestly and undoubtedly be seen to be done". 13

\section{B Why is Impartiality Required?}

In addition to giving effect to fair trial rights, ${ }^{14}$ impartiality is crucial to maintaining public confidence in the judiciary. This is conducive to the public accepting the judiciary's legitimacy. Impartiality is the precondition upon which the public adhere to the authority of judges "who are not

6 Sian Elias "Singapore Academy of Law Annual Lecture 2004: Impartiality in Judging and the Passions of Mankind" [2005] S Ac LJ at [1].

7 A former Judge of Appeal of the Supreme Court of New South Wales.

8 David Ipp "Maintaining the Tradition of Judicial Impartiality" (2009) 9 TJR 253 at 255.

9 Elias, above n 6, at [2].

10 Oaths and Declarations Act 1957, s 18.

11 Lord Bingham The Business of Judging: Selected Essays and Speeches (Oxford University Press, Oxford, 2000) at 74.

12 "Guidelines for Judicial Conduct", above n 4, at [21].

$13 R v$ Sussex Justices; ex parte McCarthy [1924] KC 256 at 259.

14 For example, the New Zealand Bill of Rights Act 1990, s 25(a). 
elected and not directly responsible to the elected branches of government". ${ }^{15}$ If the public were not confident in the judiciary, court orders would be unenforceable. ${ }^{16}$

The link between judicial impartiality and public confidence was precisely stated by Lord Denning MR, who noted that "justice must be rooted in confidence and confidence is destroyed when right-minded people go away thinking: 'the judge was biased"'. ${ }^{17}$ Therefore, impartiality is required as a matter of fact and appearance - the mere appearance of bias, whether it actually exists or not, is damaging to public confidence. On this point, the Guidelines note that the "reasonable appearance of partiality can be impossible to dispel, leaving a sense of injustice which is deeply destructive of confidence in judicial decisions". ${ }^{18}$ As such, a judge should ensure the appearance of bias does not arise by a conflict of interest, his or her behaviour in court or activities off the bench. ${ }^{19}$ Judges should also be mindful of "expressions of views which might give an appearance of bias", whether that be in or out of court. ${ }^{20}$

\section{The Law Relating to Bias}

The law on bias and recusal protects judicial impartiality and safeguards public confidence in the judiciary.

\section{Bias}

This article focuses on two forms of bias: actual and apparent bias. Actual bias refers to a situation where a judge is proven to be partial or prejudiced in some way. Actual bias is difficult to prove, requiring "direct evidence or a very strong inference that the judge was so predisposed against a party that he ... had an entirely closed mind". ${ }^{21}$ It is accepted that actual bias will seldom occur. By contrast, apparent bias covers situations where the judge is subject to an unconscious, rather than conscious, bias. $^{22}$

15 Elias, above n 6, at [2].

16 Anthony Mason "The courts and public opinion" in Geoffrey Lindell (ed) The Mason Papers: Selected articles and speeches by Sir Anthony Mason (The Federation Press, Sydney, 2007) 94 at 95.

17 Metropolitan Properties Co (Ltd) v Lannon [1969] 1 QB 577 at 598.

18 "Guidelines for Judicial Conduct", above n 4, at [23].

19 At [23].

20 At [23].

21 Grant Hammond Judicial Recusal: Principles, Process and Problems (Hart Publishing, Portland, 2009 ) at 17.

22 Saxmere Co Ltd v Wool Board Disestablishment Co Ltd [2009] NZSC 72, [2010] 1 NZLR 35 [Saxmere] at [41]. 
The test for apparent bias was precisely stated in the decision of the Supreme Court in Saxmere Co Ltd v Wool Board Disestablishment Co Ltd. Apparent bias is established if: ${ }^{23}$

A fair-minded lay observer might reasonably apprehend the judge might not bring an impartial mind to

the resolution of the question the judge is required to decide.

The test concentrates on the objective appearance of bias to the fair-minded lay observer. If that lay observer perceives a judge might not have been impartial, public confidence in the justice system could be undermined. Thus, in combination with actual bias, the law ensures that justice is done and seen to be done.

In order to decide if the apparent bias test is satisfied, it is important to understand who the fairminded lay observer is. It is clear the fair-minded lay observer is not the particular litigant to a dispute, who has a vested stake in the outcome and is thus "the least objective observer of all". ${ }^{24}$ Instead, the fair-minded lay observer "views matters objectively". ${ }^{25}$ They are "presumed to be intelligent" and are "neither unduly sensitive or suspicious nor complacent about what may influence the judge's decision". ${ }^{26}$ While the fair-minded lay observer is a not a lawyer, they are taken to know the facts and issues of the relevant case, and understand the workings of the legal system. ${ }^{27}$ In particular, a fairminded lay observer is taken to know that a judge is required to be independent and has taken an oath to this effect. ${ }^{28}$

\section{Recusal}

According to the Guidelines, "judges have an obligation to sit on any case allocated unless grounds for disqualification exist". ${ }^{29}$ This is referred to as the duty to sit and balances against judicial impartiality. The duty to sit ensures judges do not recuse too easily, at the mere suggestion of bias by a litigant. ${ }^{30}$ This duty mitigates a number of different concerns. The first acknowledges that challenging a judge's impartiality is something litigants often do as a "last-ditch remedy" because they

23 At [3].

24 At [6] and [10].

25 At [5].

26 At [5]. See also Helow v Secretary of State for the Home Department and Another (Scotland) [2008] UKHL 62, [2008] 1 WLR 2416 at [1]-[3].

27 Saxmere, above $\mathrm{n} 22$, at [5]. See also Taylor v Lawrence (Appeal: Jurisdiction to Reopen) [2002] EWCA Civ 90, [2003] QB 528 at [60].

28 Saxmere, above $\mathrm{n} 22$, at [8].

29 "Guidelines for Judicial Conduct", above n 4, at [27].

30 Gerard McCoy "Judicial Recusal in New Zealand" in in HP Lee (ed) Judiciaries in Comparative Perspective (Cambridge University Press, Cambridge, 2011) 322 at 327. 
have been unsuccessful in a case. ${ }^{31}$ Elias CJ, extrajudicially, has noted there is "no shortage" of this behaviour in New Zealand. ${ }^{32}$ Secondly, recusing too easily creates a perverse policy incentive for litigants, to "raise objections which are based solely on their desire to have their case determined by a different judge who they think is more likely to decide in their favour". ${ }^{33}$ Lastly, the duty to sit reflects the burden that frequent recusals would place on other judges and the legal system. ${ }^{34}$ This burden includes judges being overworked and time delays in cases being heard.

A judge should not hear a case where the Saxmere apparent bias test is satisfied. ${ }^{35}$ This is a question for the judge to decide, ${ }^{36}$ although a party to the litigation can suggest matters that may necessitate recusal to the judge. ${ }^{37}$ It is best practice for judges to be prudent if they are unsure whether recusal is required. ${ }^{38}$ The rationale for prudence is that a later determination that the judge should not have heard the case, requires the case to be retried, placing a greater burden on the legal system, in terms of time and expense.

\section{EXTRAJUDICIAL SPEECH: CANVASSING THE PROBLEM}

The importance of judicial impartiality and the law on bias and recusal sets the scene for this article. It is in relation to these ideas that extrajudicial speech creates concern. This Part will identify the different types of extrajudicial speech and discuss the potential problems that may arise.

\section{A The Different Types of Extrajudicial Speech}

The realm of extrajudicial speech is vast, however this article takes a narrow scope by focusing on judges' contributions to academia. The issues surrounding extrajudicial political speech are not considered. ${ }^{39}$

Judges' academic contributions cover a wide range of topics and can be presented in a variety of different forms. With regards to the latter, a judge may be published in law reviews, serve as editor of a textbook, publish a text or give public lectures and speak at conferences. It is useful to divide

31 Hammond, above n 21, at 77.

32 Elias, above n 6, at [23].

33 Saxmere, above n 22, at [88].

34 "Guidelines for Judicial Conduct", above n 4, at [28].

35 At [27].

36 At [29]; and Hammond Judicial Recusal, above n 21, at 42.

37 Christopher Forsyth "Judges, Bias and Recusal in the United Kingdom" in HP Lee (ed) Judiciaries in Comparative Perspective (Cambridge University Press, Cambridge, 2011) 361 at 375.

38 "Guidelines for Judicial Conduct", above n 4, at [29].

39 For example, Sian Elias' Shirley Smith address on sentencing policy: Sian Elias, Chief Justice of New Zealand "Blameless Babes" (Shirley Smith Address 2009, Victoria University, Wellington, 9 July 2009). 
academic writing and speaking into four further subject categories. First, judges may write on the law and current legal issues. Secondly, a judge may write on the history of the law, including biographical or autobiographical content. Thirdly, a judge may write on the judicial process, the courts and the administration of justice. Fourthly, a judge may make non-legal extrajudicial contributions, for example, by writing on the arts or history. ${ }^{40}$

This article especially focuses on writing on legal issues. This kind of writing could create concerns regarding a judge's impartiality. For example, a judge's academic writing on the law may give rise to the apprehension he has predetermined a legal matter or suggest he is biased towards a particular class of claimant. Extrajudicial writing on the other areas mentioned above is less problematic and unlikely to lead to bias and recusal issues.

\section{B The Issues Raised by Extrajudicial Speech}

Academic speech may pose serious questions for a judge's impartiality by satisfying the requirements of actual or apparent bias. ${ }^{41}$ If a judge extrajudicially expresses an opinion on a legal issue, which later comes before the judge for adjudication, he or she may have already decided the matter. That is to say, the judge may actually be biased by the extrajudicial speech. More plausibly, however, the off-bench commentary may give rise to the appearance the judge is biased and unable to bring an impartial mind to deciding the case. This would satisfy the Saxmere test.

If a judge appears to be biased based on extrajudicial statements, recusal is the proper course to take. If the judge does not, a party to the proceedings may request disqualification or may later challenge the judgment for bias. The latter is precisely what occurred in the English case of Timmins $v$ Gormley, where the defendant challenged a judgment issued for bias arising from the judge's publications in law reviews. ${ }^{42}$ The possibility of bias and the need for recusal could arise in respect of two distinct matters. First, the judge's extrajudicial writing may discuss a particular legal issue, which may create the impression a judge is biased as to the law at issue in the case. Secondly, a judge may have suggested bias towards or against a certain person or category of people who later appear in a case before that judge. For example, a judge may appear biased towards claimants in personal injury cases and against doctors giving evidence for insurers in those cases. ${ }^{43}$

Given that judges are often prolific legal writers and, especially from the appellate benches, a popular choice for public speeches and lectures, there is considerable potential for these problems to

40 Ronan Kennedy "Extra-Judicial Comment By Judges" [2005] JSIJ 199 at 212.

41 As outlined in Part II: Judicial Impartiality.

42 Locabail (UK) Ltd v Bayfield Properties Ltd [2000] QB 451 (CA) [Locabail]. Locabail was a test case on bias heard by the English Court of Appeal, consisting of a number of appeals, of which Timmins $v$ Gormley was one. The case is discussed further in this Part and in Part IV: Current Regulation of Extrajudicial Speech.

43 A similar issue arose in Timmins v Gormley, see below at Part III.B.2: England: Timmins v Gormley. 
arise. However, the scope of this problem does not appear to be large in New Zealand. The author has undertaken a survey of the extent of judicial publication in leading New Zealand law journals. Across the period 2004 to 2014, any article authored by a sitting judge of the New Zealand Courts has been recorded. ${ }^{44}$ The results of this survey are summarised in the Appendices.

A number of preliminary observations can be drawn from the survey. First, it is clear judges are published occasionally, but not frequently, in New Zealand law reviews. Over the last 11 years, on average six articles by judges were published annually. ${ }^{45}$ This is not a large amount. However, the limitations of this survey should be noted. In particular, the survey was limited to 12 New Zealand law reviews. ${ }^{46}$ It did not include any public speeches or lectures judges gave in the same period. ${ }^{47}$ Likewise, papers delivered at conferences, ${ }^{48}$ publications in foreign law reviews and textbooks authored or edited by judges were not included. Instances of extrajudicial writing would undoubtedly be found in these sources with the result that the total number of publications would be greater. Secondly, judges write on a variety of subjects. These have been categorised in Appendix 4, into four categories - specific legal topics, ${ }^{49}$ procedural topics,${ }^{50}$ historical or biographical topics, ${ }^{51}$ and other

44 By New Zealand Courts, the author refers to the Supreme Court, Court of Appeal, High Court, District Court and the specialist courts (Environment Court, Family Court, Maori Land Court and Youth Court).

45 See Appendix 1.

46 These were the Auckland University Law Review, Canterbury Law Review, Māori Law Review, New Zealand Intellectual Property Law Journal, New Zealand Journal of Environmental Law, New Zealand Journal of Family Law, New Zealand Journal of Public and International Law, New Zealand Law Review, New Zealand Universities Law Review, Otago Law Review, Victoria University Law Review and Waikato Law Review.

47 Although, it is acknowledged that speeches or lectures given by judges are sometimes reproduced in law reviews and therefore, to some extent, are implicitly included in the results collected.

48 Speeches and papers delivered at conferences can be accessed on the Courts of New Zealand website <www.courtsofnz.govt.nz>.

49 For example, Jan Doogue "Sections 15 and 15A of the Property (Relationships) Act 1976 - six years on: certainty or uncertainty?" (2007) 5 NZFLJ 282; Peter Boshier "Have judges been missing the point and allowing relocation too readily?" (2010) 6 NZFLJ 334; and Anna-Marie Skellern "The Climate Change Response Act 2002: The Origin and Evolution of s 3A - The Treaty Clause" (2012) 10 NZJPIL 167.

50 For example, Jan Doogue "A seismic shift or minor realignment? A view from the bench ascertaining children's views" (2006) 5 NZFLJ 198; Peter Boshier "Transforming dispute resolution in the Family Court" (2005) 5 NZFLJ 53; Graham Panckhurst "A Sentencing Council: Enlightened or Folly" (2008) 14 Canta LR 191: and Andrew Becroft "Access to Youth Justice in New Zealand: "The Very Good, the Good, the Bad and the Ugly"' (2011) 18 Auckland U L Rev 23.

51 For example, Sian Elias "The Life in Law of George Paterson Barton QC" (2012) 43 VUWLR 3; Ned Fletcher and Sian Elias "A Collusive Suit to 'Cofound the Rights of Property Through the Length and Breadth of the Colony'?: Busby v White (1859)" (2010) 41 VUWLR 563: and Sian Elias "Eulogy for the Lord Cooke of Thorndon" (2008) 39 VUWLR 1. 
topics. ${ }^{52}$ As suggested above, this means not all extrajudicial writing will create problems with bias and recusal. The writing on specific legal topics is most likely to create these problems and approximately 36 per cent of the articles were on this topic. ${ }^{53}$ In addition to these two conclusions, further implications ascertained from the survey will be discussed throughout the article.

On the whole, the empirical research shows it is not uncommon for judges to write extrajudicially. That, in combination with the accepted understanding that judges can and do speak off the bench, requires that further scrutiny be given to this area. It is important judges are put on notice of the possible repercussions of extrajudicial commentary and that the boundaries and guidelines governing this area, as far as they can be, are ascertained. This is especially true for the judges who have a proclivity to write extrajudicially. The results of the survey show that nearly half of all the articles published by judges were authored by Peter Boshier, former Principal Judge of the Family Court, and Elias CJ. ${ }^{54}$

The following subpart provides examples, from New Zealand and abroad, of the problems caused by extrajudicial speech.

\section{New Zealand: Judge David Harvey}

As referred to in Part I, the leading New Zealand example of recusal necessitated by extrajudicial speech relates to Judge Harvey's ${ }^{55}$ July 2012 speech at the NetHui Convention. Judge Harvey was due to hear Kim Dotcom's extradition hearing, scheduled for March 2013, when he spoke at the Convention. ${ }^{56}$ The Judge, an intellectual property law specialist, discussed the projected effect of the Trans-Pacific Partnership on New Zealand's copyright laws relating to region coding on DVDs. The Judge commented that the United States' negotiating position in this regard was particularly stringent.

52 Other topics included articles on issues that were too broad to be categorised as a specific legal topic, such as writing on the constitution or human rights. For example, Sian Elias "Mapping the Constitutional" [2014] NZ L Rev 1; ET Durie "The Rule of Law, Biculturalism and Multiculturalism" (2005) 13 Wai L Rev 14: and Peter Boshier and Julia Spelman "What's gender got to do with it in New Zealand family law?" (2011) 7 NZFLJ 61.

53 See Appendix 4. The author notes there is always the possibility that writing on procedural or other issues could lead to an apprehension of bias or necessitate recusal, however this is less likely than writing on specific legal issues.

54 See Appendix 3.

55 District Court Judge, sitting in Auckland.

56 For clarity, Kim Dotcom was the founder of a now defunct website that allowed users to share pirated files over the internet and sought for extradition by United States' authorities on charges of criminal copyright infringement, racketeering and money laundering. 
As a play on cartoonist Walt Kelly's famous punch line, "we have met the enemy and he is us", Judge Harvey concluded his speech by saying "we have met the enemy and he is U.S.". 57

This offhand remark received extensive and unfavourable media coverage. For example, a New Zealand Herald headline declared "US 'the enemy' says Dotcom judge". ${ }^{8}$ Jonathan Temm, the thenPresident of the New Zealand Law Society, criticised the media reporting, seeing it as unnecessarily sensationalist and as causing questions to arise over the Judge's impartiality. ${ }^{59}$ Applying the Saxmere test, a fair-minded lay observer might conclude Judge Harvey would not be impartial in the extradition case because of a personal bias against one of the parties - the United States. As a result of this and the widespread publicity, Judge Harvey chose to recuse himself from the case, noting the statement "could reflect on his impartiality". ${ }^{60}$ While commentators accepted this was the right result, ${ }^{61}$ they lamented the loss of Judge Harvey and his intellectual property expertise.

This incident demonstrates that a few words, in an off the cuff remark during a speech, can have drastic implications for judicial recusal. At the time Judge Harvey made the comments he was not specifically referring to Kim Dotcom, nor any of the issues raised by his extradition case. He was speaking within the niche area of region coding on DVDs and the United States' negotiating position on this. Earlier at the conference, Judge Harvey refused to comment on the extradition hearing on two separate occasions when prompted by the audience. ${ }^{62}$ The Judge had, with the exception of one minor slip in judgement, behaved with absolute propriety.

\section{England: Timmins v Gormley}

Timmins $v$ Gormley concerned a negligence action arising out of a traffic accident. The claimant, Timmins, sought damages from the defendant, Gormley, for personal injury and special damages for her lost earnings. ${ }^{63}$ The total amount sought was $£ 200,000 .{ }^{64}$ Mr Recorder Braithwaite QC, a part-

57 Chris Keall "What Judge Harvey said" The National Business Review (online ed, New Zealand, 19 July 2012).

58 Hamish Fletcher "US 'the enemy' says Dotcom judge" The New Zealand Herald (online ed, Auckland, 16 July 2012).

59 Radio New Zealand "Morning Report" (19 July 2012) Radio New Zealand <www.radionz.co.nz>.

60 David Fisher "Dotcom judge quits the case" The New Zealand Herald (online ed, Auckland, 18 July 2012).

61 For example, Grant Illingworth QC, who noted that although Judge Harvey was making a joke, the comment could lead to one of the parties to the litigation feeling that the judge was biased against them: Radio New Zealand, above n 59 .

62 Russell Brown "Judge Harvey: My part in his downfall" (19 July 2012) Public Address $<$ www.publicaddress.net>.

63 Locabail, above n 42, at [73].

64 At [73]. 
time Judge, found for the plaintiff and awarded $£ 227,000$ in damages. ${ }^{65}$ The defendant brought a cause of action alleging apparent bias. The Recorder practised in personal injury cases, mostly on behalf of claimants, was the consultant editor of the leading textbook on personal injury law and had written numerous articles on the subject. ${ }^{66}$ The bias was specifically said to arise from a small number of articles evidencing a pro-claimant, anti-insurer attitude. ${ }^{67}$ The defendant argued there was the risk the Recorder was "influenced by an unconscious but settled prejudice against the insurers of the defendant" who were the de facto defendants in the case. ${ }^{68}$ In one article, the Recorder was "highly critical of the conduct of the defendant's insurers" in a particular case and described their conduct as demonstrating "just how badly these cases can be managed". 69

The Court of Appeal in Locabail (UK) Ltd v Bayfield Properties Ltd, characterised the case as difficult to resolve and causing "particular concern". ${ }^{70}$ There was no suggestion of actual bias or a lack of good faith on the Recorder's part. In fact, he disclosed to the defendant all relevant information which may have led the defendant to request another judge, for example the Recorder's membership of the Association of Personal Injury Lawyers, which typically represented claimants. The defendant waived any objection to these factors, although the Court recognised the defendant was unaware of the articles and could not waive an objection based on them. ${ }^{71}$

In the Court's opinion, the articles demonstrated the Recorder was "very sympathetic" to claimants in personal injury cases. ${ }^{72}$ A retrial was ordered because a lay observer could not have excluded the possibility that the Recorder may "unconsciously have leant in favour of the claimant" in deciding the case. ${ }^{73}$ Thus the apparent bias test was satisfied, due to judicial bias against one of the parties.

\section{Scotland: Hoekstra v HM Advocate (No 3)}

In Hoekstra v HM Advocate (No 3), the defendants were convicted of drug offences. One of the grounds of their appeal to the High Court of Justiciary invoked art 8 of the European Convention on Human Rights and Fundamental Freedoms: the right to respect for private and family life. This was relevant because covert surveillance evidence gathered by the police was used to convict the
65 At [71].
66 At [75].
67 At [76]-[79].
68 At [72].
69 At [79].
70 At [71] and [89].
71 At [82].
72 At [78].
73 At [89]. 
defendants. ${ }^{74}$ The appeal on this ground was rejected by the bench of three judges, one of whom was Lord McCluskey. The bench was scheduled to hear the other grounds of appeal in a later hearing. Shortly after the first decision was issued, an article by Lord McCluskey was published in Scotland on Sunday, where he described the European Convention as a "Trojan Horse". ${ }^{75}$ Elaborating, Lord McCluskey described the effect of adopting the Convention as "devastating" and remarked: ${ }^{76}$

Somebody suggested to me that it was a bit like sailing in the Titanic toward a legal iceberg. My own fear is that the better simile is with an avalanche; all we can hear at the moment is a distant roar; but it is coming and we are going to have to struggle to avoid being buried in new claims of right.

Lord McCluskey specifically criticised art 8 for protecting "everyone", including "those whom the police are pursuing because they believe them to be drug dealers". ${ }^{77}$

Following publication of the article, the defendants applied to have the bench disqualified from the rest of the appeal. ${ }^{78}$ It was argued that Lord McCluskey could not be seen as impartial in relation to any future cases invoking rights under the Convention. ${ }^{79}$ Further, the defendants contended the earlier decision of the Court breached their right to be tried by an impartial judge due to apparent bias on Lord McCluskey's part. ${ }^{80}$ This issue was accordingly put before a differently constituted court for consideration.

The court found the apparent bias test was clearly satisfied by Lord McCluskey's statements, which suggested he was opposed to the Convention and its rights. ${ }^{81}$ The importance of the specific reference to art 8 was underlined as it directly related to the case. ${ }^{82}$ As a result of this finding, the appeal decision was quashed and Lord McCluskey was barred from taking any further part the appeal process. ${ }^{83}$

74 Hoekstra v HM Advocate (No 3) 2000 SLT 605 (HC) at [21].

75 At [8].

76 At [9].

77 At [10].

78 At [2].

79 At [11].

80 At [11].

81 At [22].

82 At [10].

83 At [24]. 


\section{The United States: Justice Scalia}

Justice Scalia, a Supreme Court Judge, has been embroiled in controversy because of his extrajudicial statements on two occasions. The first centres on the case of Elk Grove v Newdow, ${ }^{84}$ where the issue was whether the phrase "under God" in the Pledge of Allegiance breached the Establishment Clause of the First Amendment ${ }^{85}$ to the Constitution. ${ }^{86}$ The Court of Appeal for the Ninth Circuit found the Establishment Clause was breached. ${ }^{87}$ Justice Scalia, speaking at a religious freedom event sponsored by the Knights of Columbus, criticised this decision, emphatically stating that it was "contrary to our whole tradition". 88

At the time, leave to appeal to the Supreme Court had not been granted. However, once the case did come before the Court, the possibility was raised that Justice Scalia's comments, if not leading to actual bias, would satisfy the apparent bias test. ${ }^{89}$ In line with this, and in what was the correct decision, Justice Scalia recused himself. ${ }^{90}$ Recusal was particularly warranted because Justice Scalia had gone beyond just expressing an opinion on a legal issue: he was criticising the exact case which later came before him.

However, this result is in stark contrast to his behaviour in Hamdan v Rumsfeld. ${ }^{11}$ In this case, Hamdan, an Afghani enemy combatant detained at Guantanamo Bay, had filed a writ of habeas corpus and challenged the legality of the military trials at Guantanamo Bay, arguing they were inconsistent with provisions in the Geneva Convention. ${ }^{92}$ After the case had come before the Supreme Court, and three weeks before oral arguments were to begin, Justice Scalia gave a speech where he remarked during a question and answer session, "war is war and it has never been the case that when you capture

84 Elk Grove v Newdow 524 US 1 (2004).

85 That "Congress shall make no law respecting an establishment of religion".

86 Todd Collins "Lost in the Forest of the Establishment Clause: Elk Grove v Newdow" (2004) 27 Campbell L Rev 1 at 2.

87 At 2 .

88 David G Savage "High Court to Decide School's Pledge" The Los Angeles Times (online ed, Los Angeles, 15 October 2003).

89 The precise wording of the test for bias and the standard for recusal differs in the United States to New Zealand. Broadly speaking, in the United States a judge should recuse himself where "his impartiality might reasonably be questioned": see generally, Flanagan, above n 5, at 153.

90 Flanagan, above n 5, at 155.

91 Hamdan v Rumsfeld 548 US 557 (2006).

92 Flanagan, above n 5, at 150. 
a combatant you have to give them a jury trial in your courts ... [G]ive me a break." 93 Justice Scalia went on to say, when prompted by an audience member about the Geneva Convention: ${ }^{94}$

If he was captured by my army on a battlefield, that is where he belongs. I had a son on that battlefield 95

and they were shooting at my son and I'm not about to give this man who was captured in a war a full jury

trial. I mean it's crazy.

Justice Scalia's comments easily satisfy the apparent bias test: this is the clearest example of apparent bias of the examples mentioned in this article. Further, this is a situation where actual bias could be alleged - there is compelling evidence that Justice Scalia was so predisposed against Hamdan that he could not bring an open mind. However, Justice Scalia refused to recuse himself, even when called upon to do so by Hamdan's counsel. ${ }^{96}$ The Supreme Court decided the case in favour of Hamdan, by a margin of $5-3,{ }^{97}$ and unsurprisingly, Justice Scalia joined the dissent. ${ }^{98}$ This is a concerning result and had the Court found against Hamdan, it is hard to imagine a bias challenge would not have eventuated.

\section{CURRENT REGULATION OF EXTRAJUDICIAL SPEECH}

This Part considers how the law responds to the problems posed by extrajudicial speech. The current position is ascertained by reference to judicial conduct codes and case law. Scholarly writings on this topic are also considered.

\section{A Judicial Conduct Codes}

Judicial conduct codes do not contain enforceable rules, but rather exist to guide judges' behaviour by providing practical advice in areas of uncertainty. This Part considers the equivalent codes from New Zealand, Australia and the United Kingdom, and the recommendations made in terms of extrajudicial speech.

At a general level, all three codes offer corresponding advice on recusal based on extrajudicial statements. The New Zealand Guidelines puts the position broadly, stating a judge "should consider disqualifying him or herself if the case concerns a matter upon which the judge has made public

93 At 150

94 At 151

95 Justice Scalia's son, Matthew, did in fact serve in Iraq.

96 Flanagan, above $\mathrm{n}$, at 151.

97 Chief Justice Roberts recused himself from hearing the appeal as he had heard the case while sitting on the United States Court of Appeals for the District of Colombia.

98 Flanagan, above n 5, at 151. 
statements of firm opinion". 99 The Australian Guide to Judicial Conduct and the United Kingdom Supreme Court Guide to Judicial Conduct offer identical views referring to a judge who has expressed "strong views on topics that are relevant to issues in the case by reason of public statements "100 and where the judge has "committed ... to a particular view". ${ }^{101}$ The New Zealand Guidelines provide further direction to help judges decide whether an expressed opinion is "firm" or "strong" such that the judge should consider recusal. Specifically, the Saxmere test will not be satisfied by a judge's out of court opinion unless the expression of the opinion was "extreme and unbalanced". ${ }^{102}$

The New Zealand and Australian codes make specific provision for participation in academic writing and legal teaching, which raises similar bias issues. This extrajudicial activity is "not objectionable". ${ }^{103}$ However, the New Zealand Guidelines reiterate a judge should be careful not to articulate "firm views" about issues that may come before the court and should avoid the "appearance of pre-determining" issues. ${ }^{104}$ In a similar vein, the Australian Guide specifies, in the context of legal teaching, that if there is a "difference of views, discretion will have to be exercised - particularly where the lecturer may later have to decide the question as a judge". ${ }^{105}$ Although not expressly stated in the Guide, this direction would seemingly apply equally to academic writing - when writing on a contentious area of the law, where legal minds differ, judges would need to exercise the same discretion. By comparison, the United Kingdom's Guide is silent on this issue.

Further specific restrictions on extrajudicial speech can be discerned from the Judges' Bench Book. These relate to comments on matters of public controversy, select committee submissions and comments pertaining to a judge's own judgment. ${ }^{106}$ These will be discussed, in more depth, in Part $\mathrm{V}$.

99 "Guidelines for Judicial Conduct", above n 4, at [39].

100 The Australian Institute of Judicial Administration Incorporated Guide to Judicial Conduct (William Troedel \& Company Pty Ltd, Victoria, 2002) at [3.4].

101 "Guide to Judicial Conduct" (2009) The Supreme Court <www.supremecourt.uk> at [3.14].

102 "Guidelines for Judicial Conduct", above n 4, at [39].

103 "Guidelines for Judicial Conduct", above n 4, at [66]; and Guide to Judicial Conduct, above n 101, at [5.7].

104 "Guidelines for Judicial Conduct", above n 4, at [66] and [100].

105 Guide to Judicial Conduct, above n 101, at [5.8].

106 Grant Hammond "Judges and free speech in New Zealand" in HP Lee (ed) Judiciaries in Comparative Perspective (Cambridge University Press, Cambridge, 2011) 195 at 196-197. 


\section{B Case Law}

A number of cases across Commonwealth jurisdictions have grappled with the issues that extrajudicial speech poses. The leading decision is the English Court of Appeal in Locabail. ${ }^{107}$ The Court observed that it was not possible to conclusively list the factors that could give rise to bias as each case is fact dependent. ${ }^{108}$ With this caveat in place, the Court characterised "extra-curricular utterances, whether in textbooks, lectures, speeches, articles, interviews, reports or responses to consultation papers" as factors that would be "ordinarily unchallengeable". ${ }^{109}$ While this appears to dispense with the issue, it should not be taken as the ratio of the case, or indeed as a stringent rule. This is because the Court found, on the facts of Timmins, that apparent bias arose from the Recorder's publications in law reviews.

In respect of Timmins, the Court cautioned that a judge who writes extrajudicially in the area in which the judge adjudicates "must be circumspect in the language he uses and the tone in which he expresses himself". 110 The aim is to avoid the appearance the judge "has preconceived views which are so firmly held that it may not be possible for him to try a case with an open mind". ${ }^{11}$ The Court concluded it would always be "inappropriate" for a judge to "use intemperate language about subjects on which he has adjudicated or will have to adjudicate". ${ }^{112}$ Despite these concerns, it was suggested that extrajudicial writing was not inconsistent with the judicial function. ${ }^{113}$ The Court extolled the benefits of extrajudicial writing, as "further[ing] rather than hinder[ing] the administration of justice". ${ }^{114}$ It was purely the tone of the opinion and the "trenchancy" evident in the Recorder's expression which led to the apparent bias finding. ${ }^{115}$ Malleson critiques this decision insofar as the Court was suggesting academic writing is ordinarily unchallengeable. This conclusion is undermined by the reasoning of the Court which demonstrates there is a fine distinction between harmless academic writing and writing that gives rise to an apprehension of bias. ${ }^{116}$

107 Locabail, above n 42. The facts of one of the appeals heard in Locabail, Timmins $v$ Gormley, are stated in Part III: Extrajudicial Speech: Canvassing the Problem.

108 At [25].

109 At [25]; and Kate Malleson "Safeguarding judicial impartiality" (2002) 22 LS 53 at 61.

110 At [85].

111 At [85].

112 At [85].

113 At [85].

114 At [85].

115 At [85].

116 Malleson, above n 109, at 61. 
The statements in Locabail are almost interchangeable with the direction expressed in the Guidelines. Judges are welcome to write or speak extrajudicially in an academic capacity. However, that writing can lead to an apprehension of bias, satisfying the Saxmere test. The focus is on the expression of the writing and requires the judge to choose words carefully. The language and tone employed must not be so "intemperate" or "trenchant" so as to suggest the judge has preconceived views and cannot bring an open mind. In Timmins, the tone of the Recorder's articles implied that the Recorder had strong pro-claimant anti-insurer views, which led to the possibility the Recorder might not bring an open mind, due to bias against one of the parties - the defendant.

Another notable case is Hoekstra. ${ }^{117}$ The Scottish High Court of Justiciary found apparent bias existed, based on Lord McCluskey's Scotland on Sunday article which articulated negative views on the European Convention. Similarly to Locabail, the Court reached this conclusion based on the way Lord McCluskey's opinion was expressed. "Particular importance" was attached to the "tone of the language" and Lord McCluskey's deliberately given impression that "his hostility to ... the Convention ... is both longstanding and deep seated". ${ }^{118}$ Comparatively, if Lord McCluskey had published an article in a law review highlighting the drawbacks of the Convention in a moderate manner, no objection could be raised. ${ }^{119}$ As in Locabail, the difference was that the nature and language of the writing suggested Lord McCluskey could not be impartial in deciding cases relating to the Convention. ${ }^{120}$

This reiterates it is the mode of expression of extrajudicial writing that leads to a finding of apparent bias. Extrajudicial writing, in which a judge points out defects in the current law, or describes the benefits of the current law, in a moderate manner, is acceptable. The significance of Hoekstra, and the reason for its inclusion in this article, is that the case concerned extrajudicial statements regarding the law that led to a finding of apparent bias. It was not, as in Timmins, a bias towards a particular class of defendant, ${ }^{121}$ but rather prejudgment of a legal issue.

The New Zealand courts have not yet addressed a case with similar facts, however the courts have cited Locabail with approval. ${ }^{122}$ In Australia, cases dealing with the extra-curricular utterances of

117 Hoekstra v HM Advocate (No 3), above n 74. The facts of Hoekstra are summarised in Part III: Extrajudicial Speech: Canvassing the Problem.

118 At [23].

119 At [23].

120 At [23].

121 Although, it should be noted that Lord McCluskey's statement regarding the operation of art 9 could be interpreted as a bias against a class of defendants - drug dealers.

122 See for example Muir v Commissioner of Inland Revenue [2007] NZCA 334, [2007] 3 NZLR 495; and Director of Proceedings v Parry [2002] 2 NZLR 249 (HC). 
judges, have cited and followed Locabail. ${ }^{123}$ As such, if similar facts to Locabail or Hoekstra occurred in New Zealand, it is likely the court would adopt the guidance in the cases (and the Guidelines), by focusing on the tone and expression of the extrajudicial comment.

\section{Academic Opinion}

The prevailing academic opinion is in conformity with the guidance provided by judicial conduct codes and case law. That is, a presumption in favour of extrajudicial speech and writing, with the warning that judges should be careful to avoid their comments being a basis for a finding of bias or necessitating recusal. ${ }^{124}$

However, academic writing is more prescriptive in that academics have attempted to create a checklist of factors judges should consider before commenting extrajudicially. These factors emphasise that the context and forum in which the judge is speaking or writing is as important as the content of the extrajudicial commentary. As Kennedy notes "the wrong event, publication or audience can make innocuous remarks seem quite inappropriate". ${ }^{125}$ Collectively, these are known as time, manner and place restrictions.

The first consideration is whether extrajudicial commentary should be spoken or written. Academics agree public lectures and speeches are riskier because judges are less likely to be measured in their remarks. ${ }^{126}$ In particular, speeches create the opportunity for "spontaneous statements" and the possibility the "judge will misspeak or abandon discretion in follow up questions". ${ }^{127}$ A distinct, but equally real concern is that a judge's comments in a public speech will be taken out of context or be "misunderstood or misinterpreted" by the media, particularly where the statement is ambiguous. ${ }^{128}$ These comments are compelling and one need look no further than Judge Harvey's 2012 incident to see their force. Judge Harvey's comment that the US was the enemy was both a spontaneous statement and one that was subject to inaccurate and sensationalist media reporting. Likewise, Justice Scalia's speech prior to Hamdan provided the opportunity for audience questions, one involving the precise issue raised in the case. Despite these concerns, judges should of course be able to speak at

123 See for example Gaudie v Local Court of New South Wales [2013] NSWSC 1425; and Newcastle City Council $v$ Lindsay [2004] NSWCA 198.

124 See generally Kennedy, above n 40; William G Ross "Extrajudicial Speech: Charting the Boundaries of Propriety" (1998) 2 Geo J Legal Ethics 589; Albert Tate Jr "The Propriety of Off-Bench Judicial Writing or Speaking on Legal or Quasi-Legal Issues" (1979) 3 J Legal Prof 17; and Jonathan Lippman "The Judge and Extrajudicial Conduct: Challenges, Lessons Learned and a Proposed Framework for Assessing the Propriety of Pursuing Activities Beyond the Bench" (2012) 33 Cardozo L Rev 1342.

125 Kennedy, above n 40, at 210.

126 Ross, above n 124, at 618.

127 At 619.

128 Ross, above n 124, at 619; and Tate, above n 124, at 23. 
conferences or give public lectures. However, a judge who chooses to do so should be particularly mindful of his or her comments and refrain from making impulsive remarks, especially in response to audience questions.

The corollary of this is that writing is the better mode for extrajudicial expression. Written work enables a judge to carefully reflect on remarks and is often subject to meticulous editing. ${ }^{129}$ This reduces the likelihood any improper statement will be included in the work. Further, judges should be careful to select the proper forum for their writing. For example, publication in a law review is more appropriate than writing for a tabloid newspaper. ${ }^{130}$ This common sense suggestion also has merit newspaper articles often afford the opportunity for colourful writing, where a judge is more likely to use intemperate language. Lord McCluskey's article in Scotland on Sunday provides one such example, where the judge used descriptive metaphors, which contributed to the apparent bias test being satisfied. By contrast, the tone of a law review is more scholarly, meaning judges will temper the language they use and the expression of their writing. Despite this, there is always the risk that even a law review publication could be the basis for a bias challenge, as was the case in Timmins. As such, Ross notes "even in law reviews, a judge must be careful to avoid expressing any pronounced opinions"; there is always the need for caution. ${ }^{131}$

These time, manner and place restrictions suggested by academics are useful elaborations on the offerings of judicial conduct codes and case law. Part V will consider whether rules contained in the Guidelines should be developed, one such possibility being the inclusion of context and forum rules.

\section{REGULATING EXTRAJUDICIAL SPEECH: WHAT ARE THE COMPETING INTERESTS AT STAKE?}

Part IV of this article discussed the current regulation of extrajudicial speech. In sum, it is the tone and language used that matters - judges can express opinions as to the law extrajudicially, but must be moderate in their expression. This Part evaluates whether this position is desirable. In order to do so, the relevant interests affected by extrajudicial speech will be explored. These fall under two broad categories - judicial freedom of expression, which tends in favour of allowing extrajudicial speech, and the functioning of the legal system, which favours restricting it. These competing interests will be weighed to determine whether the current regulation strikes the right balance.

129 Ross, above n 124, at 620 .

130 Kennedy, above n 40, at 210 .

131 Ross, above n 124, at 620. 


\section{A Freedom of Expression}

\section{The current position}

In New Zealand, judges, like other citizens, enjoy the benefit of freedom of expression, conferred on them by the New Zealand Bill of Rights Act (NZBORA). ${ }^{132}$ This can be assumed by the wording of s 14, which provides that freedom of expression applies to "everyone". It is confirmed by the Basic Principles on the Independence of the Judiciary, ${ }^{133}$ art 9 of which stipulates "[m]embers of the judiciary are like other citizens entitled to freedom of expression". ${ }^{134}$ Of course, the judicial right to freedom of expression is subject to limits; it is not absolute. Butler and Butler sanction this approach, stating "public actors can benefit from [NZBORA] in principle, but their ability to benefit is subject to the concept of practicability provided for in s $29 \ldots$ and reasonable limits in s $5 " .{ }^{135}$ Section 5 provides that NZBORA rights "may be subject only to such reasonable limits prescribed by law as can be demonstrably justified in a free and democratic society". Any limit on judicial free speech must meet this condition. ${ }^{136}$ Likewise Hammond opines that the importance of free speech requires a compelling reason to limit the right - a "slight gain in total welfare will not do: there would have to be in some sense a very real overall welfare gain". ${ }^{137}$

A persuasive reason to limit the right is to ensure the values of judicial independence and impartiality are protected. The Basic Principles state freedom of expression is limited by the necessity that "judges shall always conduct themselves in such a manner as to preserve the dignity of their office and impartiality and independence of the judiciary". ${ }^{138}$ Of course, such limitations should be narrowly construed and only limit the right "no more than is reasonably necessary" to achieve the purpose of the limitation. ${ }^{139}$ Constitutional conventions and rules laid down in the Judges' Bench Book provide guidance on preserving judicial impartiality and independence. First, the Chief Justice, or Head of the Bench, with the Chief Justice's approval, should be the one to comment on matters of public

132 New Zealand Bill of Rights Act 1990, s 14.

133 Adopted by the United Nations General Assembly in 1985.

134 Basic Principles on the Independence of the Judiciary GA Res 40/32 and GA Res 40/146 (1995).

135 Section 29 suggests that the rights conferred in NZBORA apply "as far as practicable": see Andrew Butler and Petra Butler The New Zealand Bill of Rights Act: A Commentary (LexisNexis, Wellington, 2005) at [5.12.3].

136 It is beyond the scope of this article to undertake a s 5 analysis of a limit on judicial free speech. To see how this analysis would be undertaken, refer to Tipping J's judgment $R v$ Hansen [2007] NZSC 7, [2007] 3 NZLR 1 , which is the leading approach in this area.

137 Hammond, above n 106, at 210.

138 Basic Principles on the Independence of the Judiciary, above n 134.

$139 R v$ Hansen, above $\mathrm{n} 136$, at [104]. 
controversy requiring comment from the judiciary. ${ }^{140}$ Secondly, while judges are free to make select committee submissions on issues relevant to the judiciary, they should not comment on political matters. ${ }^{141}$ Thirdly, judges are not to comment on the judgments they issue, which are meant to "stand without further clarification or explanation". ${ }^{142}$

Beyond these restrictions, it is of course accepted judges are free to record their opinions on the law in the context of a judgment. $R v$ Pora is one example, where Thomas $\mathrm{J}$ described retroactive legislation as "repugnant to the rule of law". ${ }^{143}$ Hammond concludes judges enjoy this freedom outside the courtroom too. ${ }^{144}$ Similarly, in Hoekstra, the Court agreed judges could criticise or welcome developments in the law extrajudicially. ${ }^{145}$ Such writing may frustrate the executive or embarrass judges, where their statements are incorrect, ${ }^{146}$ or even lead to the need to recusal, but none of these provide a compelling reason to stop judges from writing extrajudicially. The accepted position in New Zealand, then, is that judges are entitled to free speech, as are other citizens. Reasonable limits may be imposed on this right to preserve judicial independence and impartiality, however the concerns associated with extrajudicial speech do not provide such a rationale.

\section{Reasons to protect judicial free speech}

It is necessary to consider why the right to judicial free speech should be protected. Generally, a number of justifications are advanced for protecting free speech. ${ }^{147}$ The most relevant justifications to judicial speech relate to truth and self-fulfilment.

This argument from truth seeks to enable the discovery of truth. If freedom of expression is restricted, society is inhibited from discovering what the truth is. ${ }^{148}$ The theory has been recast as the "marketplace of ideas" in the United States, positing the best way to discover the truth is through an unrestricted flow of debate. ${ }^{149}$ In terms of judicial free speech, Hammond labels the argument from

140 Hammond, above n 106, at 196.

141 At 197.

142 At 197.

143 At 213; and Rv Pora [2001] 2 NZLR 37.

144 Hammond, above n 106, at 214-215.

145 Hoekstra, above n 74, at [23].

146 Hammond, above n 106, at 215.

147 Eric Barendt Freedom of Speech (2nd ed, Oxford University Press, Oxford 2005) at 6-12; and Butler and Butler, above n 135, at [13.6.2]-[13.6.14].

148 Barendt, above n 147, at 7.

149 Butler and Butler, above n 135, at [13.6.2]-[13.6.3]; and Barendt, above n 147, at 11. 
truth as "very powerful", as there must be truth in justice. ${ }^{150}$ Hammond is referring specifically to speech within the confines of a judgment, where a judge comments on the injustice of the operation of a particular statute. ${ }^{151}$

However, the argument applies equally to extrajudicial speech. Off the bench, judges make contributions to academia on particular legal issues. It is important there is a free flow of these ideas and that they are publicly available because of the educative benefit they provide. Judges are at the peak of the legal profession. They are highly skilled and hugely knowledgeable in the law, having studied and practised widely prior to their appointment to the bench. They are amongst the best legal minds in New Zealand. Their academic writing offers insight and exposes society to novel legal arguments. This work helps to educate academics, lawyers and law students; its value cannot be overstated. This argument is particularly persuasive in a New Zealand context where, given the smaller size of the legal profession, there is reliance on the contributions judges make to academia. The empirical research collated shows this is especially true in the area of family law, where judges make significant contributions to the New Zealand Family Law Journal. ${ }^{152}$ This is presumably because fewer academics specialise in this area and practitioners are often too busy to write, leading to a paucity of contributions. In such a situation, the extrajudicial writing of judges sitting on the Family Court benches is an invaluable resource for the legal profession.

In addition to substantive legal issues, judges also write on procedural issues and the functioning of the justice system. ${ }^{153}$ This writing is equally valuable given the unique perspective judges possess. Judges witness how the legal system operates first hand and are best placed to comment on its deficiencies and the procedural problems that arise. It is important this writing is available, so that such issues can be known. For example, Judge Harvey has recently written on the challenges posed to jury trials by the information jurors may access on the internet and how the courts should respond. ${ }^{154}$ This procedural issue is one that perhaps only judges are privy to, making their extrajudicial writing invaluable. Likewise, the New Zealand Family Law Journal contains numerous articles by judges on procedural issues, such as whether judges should meet with the children at the centre of Family Court cases. ${ }^{155}$ It is unsurprising that Mason, writing at the time he was a Judge on the New South Wales Court of Appeal, noted "significant contributions to the marketplace of ideas

150 Hammond, above n 106, at 213

151 Such as $R$ v Pora, above n 143; Hammond, above n 106, at 213.

152 See Appendix 1.

153 See Appendix 4 for a list of articles written by judges on procedural issues.

154 David Harvey "The Googling Juror: The Fate of the Jury Trial in the Digital Paradigm" [2014] NZ L Rev 203.

155 Ian Mill "Conversations with children: a Judge's perspective on meeting the patient before operating on the family" (2009) 6 NZFLJ 72. 
have been made in recent years by serving judges speaking or writing in their private capacities". 156 Ross goes as far as to say a "cloistered judiciary ... would impoverish society". ${ }^{157}$

In contrast to the argument from truth, which focuses on the consequential benefits that accrue from free speech, the argument from self-fulfilment relates to the "intrinsic importance of speech to each individual". ${ }^{158}$ As Barendt accurately describes, "a right to express beliefs ... reflects what it is to be human". ${ }^{159}$ Free speech is an essential part of an individual's self-fulfilment, and without the ability to speak and write freely, that individual's life is poorer and their self-development lessened. Extrajudicial free speech can be justified on this basis. Writing judgments affords judges only limited scope for expressing their opinions and beliefs. In a judgment, a judge expresses opinion as to the legal issues directly relevant to the resolution of the case, or if making an obiter statement, a legal issue that is tangentially linked to the case. It is only in the realm of extrajudicial speech that a judge has a free reign to write on what he or she wants to. This work is undoubtedly intellectually satisfying for the judge and contributes to the judge's personal growth. Judges have noted this exact benefit of extrajudicial speech. For example, Ripple ${ }^{160}$ noted extrajudicial writing provided the opportunity for "intellectual enrichment" and "put the jurist in touch with a broader world of ideas". ${ }^{161}$

In a practical sense too, allowing judges the ability to express themselves extrajudicially provides benefits. Noonan ${ }^{162}$ argued that the "most benefited person" is the judge, who "attain[s] greater clarity of thought through the discipline of writing", "acquir[es] mastery over one subject" and "develops a fluency of style and ease of expression" through extrajudicial writing. ${ }^{163}$ While this may be overstating the position somewhat, in that judges are no doubt already skilled writers, Noonan is correct to identify that judges themselves benefit from academic writing. Further, extrajudicial writing contributes to increasing the skills and capabilities of the judiciary as a whole. ${ }^{164}$ These practical benefits accrue to society. Indeed, there is a public interest in having a highly skilled judiciary as collectively, they will render better judgments. This and the other practical benefits of judicial free

156 Keith Mason, President of the New South Wales Court of Appeal "Should Judges Speak Out?" (JCA Colloquium, Uluru, 9 April 2001).

157 Ross, above n 124, at 641.

158 Hammond, above n 106, at 210.

159 Barendt, above n 147, at 13.

160 Senior Circuit Judge on the United States Courts of Appeal for the Seventh Circuit.

161 Kenneth F Ripple "Judges on Judging: The Judge and the Academic Community" (1989) 50 Ohio St L J 1237 at 1241 .

162 Judge on the United States Courts of Appeal for the Ninth Circuit.

163 John T Noonan Jr "Judges as scholars: Are they? Should they be?" (2000) 84 Judicature 7 at 9.

164 Lippman, above n 124, at 1385. 
speech and the importance of protecting it as a principle must be taken into account in deciding how it should be regulated.

\section{B Functioning of the Legal System}

The other main consideration in deciding how extrajudicial speech should be regulated is the administration of justice. There are a number of sub-issues that fall under this head.

\section{Maintaining judicial impartiality}

It is essential that judicial impartiality is maintained. ${ }^{165}$ To reiterate, an impartial judiciary is necessary to maintain public confidence in the judiciary and in turn, ensure the public accepts the legitimacy of the judges. Extrajudicial writing may undermine judicial impartiality. To the extent that such writing suggests the judge is actually biased or, gives rise to an apprehension of bias, the judge's impartiality is called in to question. If these occurrences were widespread, public confidence in the judiciary would decline. ${ }^{166}$ This weighs against judicial free speech and could justify the imposition of a limit on free speech, in order to protect judicial impartiality. That being said, a limit may be unnecessary. Judicial impartiality may be sufficiently protected as long as a judge is willing to recuse him or herself where his impartiality is questioned and the Saxmere test satisfied. Insofar as this becomes established as the norm of judicial practice, a positive limitation on free speech may not be required.

\section{Problems caused by a policy of recusal}

However, there is potential for the policy of recusal to impact on the efficient and effective functioning of the legal system. Although it is important to err on the side of caution with regards to requests to recuse, judges should not recuse too easily. Once judges have recused themselves on the basis of an apprehension of bias arising from extrajudicial writing, they will have to do so whenever that issue arises. If the issue is a narrow factual or legal one, it may not pose a problem for the administration of justice, but where the issue is wider, recusal would be frequently necessitated. For example, following Hoekstra, Lord McCluskey would be precluded from hearing any case that in any relevant way relied on the European Convention. ${ }^{167}$ This would be equivalent to a New Zealand judge expressing extreme dislike for NZBORA and then being forced to recuse him or herself, repeatedly, from any case invoking NZBORA rights. Thus, where the issue giving rise to alleged bias is not

165 See Part II: Judicial Impartiality.

166 Ross, above n 124, at 615.

167 This specific concern did not arise in Hoekstra as Lord McCluskey was a retired judge, appointed to sit on the bench in Hoekstra through a specific Scottish statutory provision, however it plausibly could arise in other cases. 
discrete, but one that could be connected to any number of future cases, judges may need to recuse repeatedly.

Frequent recusals may cause two further subsidiary issues to arise. First, judges are most likely to write and speak extrajudicially in their area of legal expertise meaning their recusal will be necessitated in this area. This may be harmful to the effective functioning of the judicial system as judges who are best placed to hear cases due to their expertise may be precluded from hearing them. For example, Judge Harvey, an intellectual property law expert, was precluded from hearing Kim Dotcom's extradition case, which invoked copyright issues. However, as New Zealand does not have an overt policy of judicial specialisation, ${ }^{168}$ this would be coincidental, rather than a frequent problem. The better example is with judges who sit on specialist courts and write extrajudicially within that area of specialty. The large number of writings by Family Court judges, on specific issues in family law, may be seen as more concerning in this regard. ${ }^{169}$ Secondly, a policy of recusal is especially problematic where the judge sits on an appellate bench, and recusal leaves the court a judge short. The Supreme Court Act 2004 requires an acting judge be appointed in this event, so that a full bench of five is constituted. ${ }^{170}$ However, even this is an additional burden on the legal system. The fact Supreme Court judges account for a sizeable portion of articles published by judges in New Zealand increases the chances of this occurring. ${ }^{171}$

\section{False bias claims}

The final consideration stems from the not uncommon practice of unsuccessful litigants bringing empty bias claims in the hope of having a previous judgment overturned. As noted in Part II, Elias CJ has remarked there is "no shortage" of litigants bringing these sorts of bias claims. ${ }^{172}$ This is an already troubling practice, which unnecessarily occupies judicial time and resources. As such, it is essential the approach to regulating extrajudicial speech does not encourage this behaviour to continue. If the standard for a finding of apparent bias based on extrajudicial speech is too low, there is the risk it may be used as a vehicle for empty bias claims. This would frustrate judicial resources

168 John Katz "Access to Justice from the Perspective of the Commercial Community: Judicial Specialisation" (2012) 18 Auckland U L Rev 37 at 37.

169 Family Court judges account for 41per cent of the articles published by judges in New Zealand law reviews between 2004-2014: see Appendix 2, Table 2.2. For a list for articles published by Family Court judges on specific legal issues refer to Appendix 4.

170 Supreme Court Act 2003, s 23. For more information see Michael Taggart "Acting Judges and the Supreme Court" (2008) 14 Canta LR 217.

171 Of the extrajudicial publications in New Zealand law reviews between 2004-2014, Supreme Court judges accounted for 23 per cent of articles published: see Appendix 2, Table 2.2.

172 Elias, above n 6, at [23]. 
and reduce the efficiency of the legal system. The threshold must be sufficiently high to ensure this behaviour does not occur.

\section{Does Current Regulation Strike the Right Balance?}

The current regulation of extrajudicial speech adequately accommodates the competing considerations outlined above. The status quo recognises the right to judicial free speech by imposing no sweeping restrictions on what a judge can say extrajudicially. This acknowledges that judges can express opinions on the law beyond the parameters of a judgment. At the same time, judicial impartiality and public confidence are protected by allowing such commentary to be the basis of actual or apparent bias and requiring recusal where the Saxmere test is satisfied. This approach does rely on a judge being willing to recuse where his or her impartiality is questioned. Hypothetically, it is possible a judge might refuse to recuse him or herself, as Justice Scalia did in Hamdan. ${ }^{173}$ However, there is no reason to think this would be the norm; in New Zealand, Judge Harvey immediately recused himself once the media publicised his comment. In any case, if a judge refused to recuse where he or she ought to have done so, any concern is ameliorated by the fact a litigant could bring a cause of action alleging bias.

Further, the threshold for apparent bias and recusal is pitched at a sufficiently high level. Case law and judicial conduct codes mandate there must be something unique about extrajudicial writing or speech before the Saxmere test is satisfied; its mere presence is not enough. The requirement that the tone and language employed must be intemperate before the test is satisfied protects the efficient and effective functioning of the judicial system. Since the Saxmere test will rarely be met, the legal system will not be impacted by frequent recusals and the concomitant problems this causes. This threshold also dissuades empty bias claims, as litigants will have to do far more than merely identify an instance of extrajudicial writing or speaking on a relevant issue before the bias claim is successful.

Although it is accepted that the status quo balances the competing interests correctly, it is not without its flaws. In particular, the current guidelines are difficult to apply in practice. It is difficult to pinpoint precisely what language and tone will be deemed trenchant and what is the permissible expression of an opinion. It is a fine line and judges are likely to differ in their application of this standard. Lippman notes this "is not an exercise amendable to bright-line rules" as each case depends on its facts. ${ }^{174}$ Lord Bingham argues that in the area of professional conduct and responsibility, such as judicial bias, there is a need for "a clearly defined rule which ... judges can readily absorb and apply". ${ }^{175}$ It is doubtful whether the law as it stands achieves this: while the rule is consistently stated, it is difficult to apply.

173 See Part III: Extrajudicial Speech: Canvassing the Problem.

174 Lippman, above n 124, at 1385-1386.

175 Lord Bingham "What is the law?" (2009) 40 VUWLR 597 at 610. 
Despite the deficiencies of the current regulation, it is unclear whether the creation of further more specific rules would help. Perhaps more guidance needs to be provided as to what constitutes a "trenchant" or "intemperate" tone? However, this may be undesirable and only have a chilling effect on legitimate extrajudicial speech. ${ }^{176}$ One approach could be to include examples of impermissible speech, such as Hoekstra or Timmins, so that judges have a standard to measure their speech against. It may be that the time, manner and place suggestions noted by academics should be incorporated into the Guidelines as a practical reference point for judges. But, these are common sense recommendations and may not be especially useful in helping judges determine if their writing or speech has crossed some poorly defined line.

Most academics acknowledge this problem with definition but accept that the status quo is satisfactory. However, some commentators have taken a vastly different approach, as discussed in the following Part.

\section{REFORM: THE SOUND OF SILENCE?}

This Part will consider whether a policy of judicial silence should be adopted in response to the problems posed by extrajudicial commentary. This is the suggestion put forward by Australian academics Bartie and Gava. Their argument will be broken down and discussed and then a critique will be provided.

\section{A Bartie and Gava's Argument for Judicial Silence}

\section{The problem with extrajudicial writing}

Bartie and Gava write from the assumption that common law judging is creative and that in espousing the law, a judge is stating what he or she thinks the law should be. ${ }^{177}$ In this context, once a judge has expressed a view on the law extrajudicially, a legal issue which the judge may be later required to decide has been prejudiced. ${ }^{178}$ In other words, the Saxmere apparent bias test is satisfied. This problem arises in regards to all academic writing on live legal issues, which are controversial issues the courts may adjudicate on in the future. ${ }^{179}$ This narrows the scope of extrajudicial writing considered in this article, to a subset of academic writing.

Certain characteristics of academic writing contribute to the alleged bias problem. First, the method of academic writing mirrors judgment writing, as a judge will survey the common law authorities on a legal point, then decide how the issue should be resolved, much as in a judgment. ${ }^{180}$

176 Ross, above n 124, at 641

177 Bartie and Gava, above n 2, at 640-641.

178 At 641 .

179 At 641 .

180 At 641 
Secondly, the writing is a "crystallisation of the judge's opinion in print". ${ }^{181}$ Rather than being tentative, it is the result of ample time and intellectual effort, meaning a judge is committed to the position stated. ${ }^{182}$ Thirdly, since the work is publicly available to practitioners and other academics, a judge has an increased "investment" in it and will try hard to perfect it. ${ }^{183}$

Following from this, Bartie and Gava disagree with the premise underpinning the current regulation of extrajudicial speech, that the tone and expression of the writing is significant. Part IV discussed this approach, which affirms that a judge's written expression needs to be intemperate before any issue of prejudgment arises. Bartie and Gava reject this approach as being unconvincing and contend that dispassionate legal writing is equally likely to lead to prejudgment. ${ }^{184}$ The corollary of this is that any extrajudicial writing on a live legal issue would satisfy the apparent bias test and require a judge to recuse him or herself from hearing the case. This has wide ranging implications given the proclivity of judges to write extrajudicially.

\section{Examples}

Bartie and Gava provide two Australian examples illustrating the concerns identified in extrajudicial writing. The first is an article on malicious prosecution, published by Ipp $\mathbf{J}$ in the Australian Law Journal. ${ }^{185}$ In the article, Ipp surveys the common law on, and policy arguments pertaining to, malicious prosecution and concludes that his judicial colleague incorrectly decided a recent case. The article mirrors the approach a judge would take if confronted with the issue in a case, presenting the risk that if that occurred, Ipp would merely replicate his article, rather than resolving the case on its merits. ${ }^{186}$ The second example relates to judges who serve as textbook editors. In two particular appeal decisions, ${ }^{187}$ the judges sitting have criticised the trial judges' decisions extrajudicially in a textbook and decided the appeals in line with that criticism. ${ }^{188}$ Bartie and Gava are concerned by this practice and believe it is a clear example of prejudgment. ${ }^{189}$

\section{At 641 .}

182 At 641 .

183 At 641.

184 At 644.

185 Ipp J is a New South Wales Court of Appeal Judge. The article Bartie and Gava refer to is: D A Ipp "Must a Prosecutor Believe that the Accused is Guilty? Or, Was Sir Frederick Jordan Being Recalcitrant?" (2005) 79 ALJ 233.

186 Bartie and Gava, above n 2, at 649.

187 Harris v Digital Pulse Pty Ltd (2003) 56 NSWLR 298 (NSW CA); and Farah Constructions Pty Ltd v SayDee Pty Ltd (2007) 230 CLR 89.

188 Bartie and Gava, above n 2, at 649-650.

189 At 651. 


\section{Counter arguments}

Having established their thesis, Bartie and Gava consider the arguments against their position. The main defence of academic writing is that a judge can distance him or herself from extrajudicial work and will not blindly apply the expressed opinion should the same issue arise in a case. Bartie and Gava concede a judge may be capable of doing this on occasion, however they believe it is naïve to assume judges will do so regularly. ${ }^{190}$ Rather, there is an ever pervasive risk a judge will follow what was written extrajudicially because "that is the way human nature works". ${ }^{191}$ A similar argument is made by Bickel, who thought extrajudicial writing could lead to prejudgment because "nothing is more persuasive to us than our own published prose". 192

Bartie and Gava are also careful to distinguish extrajudicial writing from a judge's work prior to appointment and their written judgments. This distinction is a necessary one. The logical extension of Bartie and Gava's argument is that a judge's publications while an academic, and advocacy work while a barrister, would lead to prejudgment. This would mean a judge would have prejudged all live legal issues encountered in working life. If this was true, Bartie and Gava's argument is nonsensical. However, this outcome is precluded by the judicial appointment process. The "private decision to become a judge" and "public affirmation to judge according to the law and merits of the case", through taking an oath, are argued by Bartie and Gava to cleanse a judge of ties to legal positions held before appointment. ${ }^{193}$ Judgments are also different to academic writing. Context is important here: judgments require a judge, as a part of their job, to form opinions on the law, in regard to a distinct set of facts, having had the benefit of hearing arguments on the law by counsel. By contrast, academic writing is purely voluntary, written by a judge to give "effect to purely personal preferences", absent facts and legal argument. ${ }^{194}$

\section{The solution}

The solution to this bias problem is described as "simple": "busy judges should not write about moot legal problems". ${ }^{195}$ Rather than any law change, Bartie and Gava envisage a self-imposed ban - a form of judicial self-censorship, characterised as one of the many duties incumbent on judges upon their ascension to the bench. ${ }^{196}$ Judicial recusal is seen as an inadequate solution. The scope of

190 At 651 .

191 At 651 .

192 Hearings on Nonjudicial Activities of Supreme Court Judges and Other Federal Judges, before the Subcomm. On Separation of Powers (91st Cong, 1st Sess, 1969) at 142, as cited in Ross, above n 124, at 613.

193 Bartie and Gava, above n 2, at 654.

194 At 655 .

195 At 657 .

196 At 657. 
the problem, as characterised by Bartie and Gava, is so wide that the legal system would be unable to sustain the widespread recusal that would occur. ${ }^{197}$

\section{B Critique}

\section{Prejudgment}

This article argues that Bartie and Gava's hypothesis is principally and practically wrong. The first premise requiring further analysis is whether the problem of prejudgment applies in respect of all extrajudicial writing on live legal issues. Bartie and Gava contend that it does. A different approach, focusing on the tone and expression of writing, is ascertainable in judicial conduct codes and case law. ${ }^{198}$ A different approach again is put forward by Finn, writing specifically in response to Bartie and Gava. Finn distinguishes between the making of factual findings and determinations of what the law is, and argues it is only extrajudicial statements on the facts that raise the possibility of bias. ${ }^{199}$ For example, where a judge has, in extrajudicial writing, expressed doubts as to the credibility of a certain class of witness, this may raise an apprehension of bias. ${ }^{200}$ Comparatively, merely taking a stance on a legal issue will not give rise to such an apprehension.

Finn states the proposition too strongly. It is clear apparent bias can arise from statements concerning the law. This is demonstrated by Hoekstra, where Lord McCluskey's extrajudicial statements on the merits of the Convention were held to give rise to the appearance of bias. Cases such as Locabail indicate that a judge who writes extrajudicially must be "circumspect in the language he uses and the tone in which he expresses himself" lest a finding of apparent bias be made. ${ }^{201}$ Such statements are general, not particularised and narrowed towards statements as to the facts, and certainly broad enough to encompass statements concerning the law. The majority of academic opinion is also in favour of this position. Hammond, for example, in his text on judicial recusal, suggests extrajudicial writing on a question of law or criticism of the approaches taken by other judges, could result in apparent bias. ${ }^{202}$

However, it is incorrect to assert that all academic writing automatically results in prejudgment. The correct position falls between the two extremes: extrajudicial writing on a legal matter can, but will not necessarily, lead to apparent bias. This conclusion is reached through consideration of the

197 At 657 .

198 See Part IV: Current Regulation of Extrajudicial Speech.

199 Chris Finn "Extrajudicial Speech and the Prejudgment Rule: A Reply to Bartie and Gava" (2014) 34 Adel L Rev 267 at $268-269$.

200 At 270

201 Locabail, above n 42, at [85].

202 Hammond, above n 21, at 133. 
Saxmere test and the characteristics of a fair-minded lay observer. ${ }^{203}$ In short, the fair-minded lay observer is not unduly suspicious, is informed of the workings of the legal system and is taken to know that a judge has sworn a judicial oath to decide cases impartially. ${ }^{204}$ Bearing this in mind, it is unlikely a fair-minded lay observer would assume a judge was unable to decide a case impartially because of the mere existence of extrajudicial writing on a relevant legal matter. A fair-minded lay observer knows of the tradition of judicial impartiality and that the very nature of a judge's job requires him to put aside his views, whether expressed or unexpressed, when hearing a case. Knowing this background information, a fair-minded lay observer would have to be unduly suspicious before entertaining the idea a judge may be biased by a single piece of academic writing.

Plainly, something more than the existence of extrajudicial writing is needed before bias is apprehended. That "something more" derives from the tone of the writing and the language the judge uses. If the foregoing is extreme and unbalanced, a fair-minded lay observer is more likely to assume the judge is inflexible, dedicated to the expressed opinion and less able to bring an open mind. Thus, contrary to what Bartie and Gava suggest, the tone of the extrajudicial writing is crucial to a finding of prejudgment. As such, the examples Bartie and Gava refer to are only concerning insofar as judicial authors adopted this kind of tone. This also dispenses with the need to distinguish legal positions articulated by the judge prior to appointment on the arbitrary basis of taking a judicial oath.

\section{Academic writing}

Bartie and Gava's observations on academic writing are also open to criticism. Academic writing, rather than being a crystallisation of the judge's opinion, may well be tentative. Because it is written in the abstract, in a situation devoid of facts and arguments of counsel, judges may simply be hypothesising or testing a legal argument to see its academic reception. There is always the possibility a judge will decide a case differently because of the factual matrix, counsel's arguments or indeed the arguments his or her colleagues make. Glazebrook $\mathbf{J}$, writing extrajudicially in a paper on tax avoidance, noted there was no "guarantee" the interpretation of tax avoidance cases she put forward "would survive argument in court and collegial discussion of those arguments" in a later case, or that it would be endorsed by the Supreme Court. ${ }^{205}$ Some may argue this disclaimer is only empty words, however, the better argument is that a judge's extrajudicial writing is not that judge's final opinion on an issue.

203 As discussed in Part II: Judicial Impartiality.

204 Saxmere, above $\mathrm{n} 22$, at [5] and [8].

205 Susan Glazebrook "Statutory Interpretation, tax avoidance and the Supreme Court: Reconciling the specific and the general" (paper presented at the New Zealand Institute of Chartered Accountants 2013 Tax Conference, Auckland, November 2013) at 2. Heath J takes a similar approach in Paul Heath "Some thoughts on a (New Zealand) judicial approach to trust law" (paper presented at the Society of Trust and Estate Practitioners New Zealand Conference, Auckland, 29 March 2012) at [1]. See also Ross, above n 124, at 613. 
Further, Bartie and Gava's suggestion a judge is invested in his extrajudicial work and wants the legal profession to remain confident in it is also a tenuous argument. Judges in the lower echelons of the court structure, and indeed all judges at some stage in their judicial career, have had their judgments criticised and overturned on appeal or scrutinised by academics. Judges are more thickskinned than Bartie and Gava give them credit for and suggesting judges are so sensitive to criticism is not suited to the realities of their profession.

\section{Solution}

Bartie and Gava's solution of judicial silence is predicated on the fact that every instance of extrajudicial writing on a live legal issue results in prejudgment. Once it is accepted that this is not the case, judicial silence is an overreaction. The need to recuse would only seldom arise, when the tone and language used in an article were intemperate. The rarity of the problem is further emphasised by the empirical research conducted, which highlights the low level of extrajudicial writing by judges in New Zealand law journals. ${ }^{206}$ To silence judges in this context is wholly unnecessary and defies common sense. Instead, the status quo approach of recusal is entirely appropriate. Given that recusals would be infrequent, this would not put an undue strain on the judiciary as Bartie and Gava suggest.

\section{Other Objections to Judicial Silence}

In addition to the doctrinal problems identified, there are sound policy reasons why judicial silence could not be adopted. First, Bartie and Gava's proposal can be seen as an unjustified incursion on judicial free speech. The restriction is clearly aimed at preserving judicial impartiality and public confidence in the judiciary. However, it is not a reasonable limit that can be demonstrably justified in a free and democratic society; ${ }^{207}$ it is far too wide. To effectively muzzle judges and prevent them from writing or speaking extrajudicially on any live legal issue, for example, by amending the Judges' Bench Book to that effect, is to significantly deprive the judiciary of their right to free expression. This would be tantamount to a return to the anachronistic Kilmuir Rules that governed extrajudicial speech from 1950-1970. The Rules originated with a statement by Lord Kilmuir, the Lord Chancellor of Great Britain, that: ${ }^{208}$

So long as the Judge keeps silent, his reputation for wisdom and impartiality remains unassailable ...

every utterance which he makes in public ... must necessarily bring him within the focus of criticism.

206 See Appendix 1.

207 New Zealand Bill of Rights Act, s 5. See Part V: Regulating Judicial Speech: What Are the Competing Interests at Stake?

208 Letter from Lord Kilmuir (Lord Chancellor of Great Britain) to Sir Ian Jacob KBE (Director-General of the BBC) (12 December 1995), as cited in Lord Neuberger of Abbotsbury, Master of the Rolls "Where Angels Fear to Tread" (Holdsworth Club 2012 Presidential Address, England, 2 March 2012), at [7]. 
The modern approach to judicial free speech has vastly progressed from the Kilmuir Rules, and Bartie and Gava fail to demonstrate any cogent reasons to justify a reversion to the Rules.

From a practical perspective, a policy of judicial silence is also unattractive. Judges need an outlet to express their opinions as to the law, which extrajudicial writing provides. If this outlet is taken away, it is possible judgments will take its place and will be stacked with superfluous comments that judges are otherwise unable to express. The increased amounts of obiter dicta in judgments, only vaguely related to the legal issues in a case, will reduce the clarity and precision of the law. Further, the public will be deprived of the valuable educative resource extrajudicial writing provides. A judge's extrajudicial writing on unresolved legal issues is of huge value to the legal profession, especially given the small size of the profession in New Zealand. ${ }^{209}$

That said, the author accepts the practice of self-censorship, which some judges choose to adopt. Felix Frankfurter described his time spent serving on the United States Supreme Court as one where he was plagued by "judicial lockjaw", a form of judicial restraint that stopped him from participating in extrajudicial activities. ${ }^{210}$ In the same way, Mason reminds us that some judges "maintain that their job is to speak only through their judgments", as is their right to do. ${ }^{211}$ It is entirely acceptable if a judge chooses, for personal reasons, not to participate in extrajudicial activity. However, it would be wrong to mandate this practice in the Judges' Bench Book or Guidelines.

\section{WHY DOES THIS EVEN MATTER? A LEGAL REALIST CRITIQUE}

A legal realist would object to the main contention of this article, that extrajudicial writing can raise issues of bias. As a critique, this Part considers the objections a legal realist might raise.

\section{A The Legal Realist Argument}

According to legal realist theory, common law judging is not a mechanistic process of merely applying precedent, but is somewhat creative. Interpreting the law and applying it to the facts is not a clear-cut exercise and vests a judge with discretion. That discretion is exercised in a way that reflects a judge's opinion as to what the law should be and the judge's broader worldview. As such, the decision rendered depends very much on the identity of the individual judge. Two judges adjudicating identical cases may come to opposing conclusions as their subjectively held beliefs come to bear on the

209 See Part V: Regulating Judicial Speech: What Are the Competing Interests at Stake? for further discussion.

210 Leslie B Dubeck "Understanding "Judicial Lockjaw": The Debate Over Extrajudicial Writing" (2007) 82 NYU L Rev 569 at 569.

211 Mason, above n 156. 
decision. ${ }^{212}$ That is to say, judges are "influenced by their political and moral views and by their personal biases" in rendering decisions. ${ }^{213}$

According to legal realists, judges bring with them to the bench their own worldview. For example, Cardozo opined in his seminal work, The Nature of Judicial Process, that: ${ }^{214}$

There is in each of us a stream of tendency, whether you choose to call it philosophy or not, which gives coherence and direction to thought and action. Judges cannot escape that current any more than other mortals. All their lives, forces which they do not recognise and cannot name, have been tugging at them

- inherited instincts, traditional beliefs, acquired convictions; and the resultant is an outlook on life, a conception of social needs.

Cardozo went on to remark that judges "do not stand aloof on ... chill and distant heights"; "the great tides and currents which engulf the rest of men do not turn aside in their course and pass the judges by". ${ }^{215}$ Judges, like all others, are affected by "likes and dislikes ... predilections and ... prejudices ... instincts and emotions and habits and convictions". 216

More narrowly, and most pertinent to this article, judges undoubtedly have their own opinions on the law. This colours what judicial impartiality means. Judge Jerome Frank noted in Re JP Linahan Inc that if impartiality meant "the total absence of preconceptions in the mind of a judge, then no one has ever had a fair trial and no one ever will". ${ }^{217}$ In Laird v Tatum, Justice Rehnquist similarly stated that if a judge's mind was "a complete tabula rasa ${ }^{218}$ in the area of constitutional adjudication" that would demonstrate the judge was not qualified, rather than not biased. ${ }^{219}$ Even Elias CJ acknowledges that "good judges will not be ideological virgins when appointed". ${ }^{220}$ In this context, impartiality does not mean having no opinions as to the law; it is inevitable that all judges do.

These opinions and a judge's broader worldview influence how judicial decisions are resolved. Tamanaha remarks that "how judges interpret the rules will be a function of their personal views and

212 W William Hodes "Bias, the appearance of bias, and judicial disqualification in the United States" in HP Lee (ed) Judiciaries in Comparative Perspective (Cambridge University Press, Cambridge, 2011) 379 at 382.

213 Brian Z Tamanaha "Understanding Legal Realism" (2008) 87 Tex L Rev 731 at 732.

214 Benjamin N Cardozo The Nature of Judicial Process (Yale University Press, New Haven, 1921) at 12.

215 At 168 .

216 At 167.

217 Re JP Linahan 138 F 2d 650 (1943) at 651.

218 Translation: "blank slate".

219 Laird v Tatum 409 US 824 (1972) at 835.

220 Elias, above n 6, at [42]. 
the surrounding social forces". ${ }^{221}$ Likewise, Cardozo was of the opinion that "when reasons are nicely balanced" a judge's instincts, beliefs and convictions, "determine where choice shall fall".222 The problem of extrajudicial writing falls in this context. Once it is acknowledged that a judge's mind is not a blank slate and that opinions held come to bear in the judge's judgments, extrajudicial writing is perceived in a very different light. In particular, the choice is not between judges who have no opinions or inherent biases, and judges who do and who have expressed these thoughts extrajudicially. All judges are equally subject to predilections, whether captured in writing or not. Contextualising the issue, the Recorder in Timmins, for example, has a partiality towards claimants and against insurers irrespective of whether this has been expressed extrajudicially.

Following from this, extrajudicial writing is beneficial because it exposes the opinions the judge holds. Transparency is enhanced when a judge acknowledges his worldview and approaches to judging extrajudicially. This is helpful to individual litigants appearing before the judge who are informed of possible adverse views the judge has. ${ }^{223}$ This enables litigants to tailor their submissions and oral arguments to address the judge's concerns. In a broader sense, Reinhart ${ }^{224}$ argues the writing serves a public good: ${ }^{225}$

There is no good reason for judges to attempt to conceal the fact that we approach the law with differing judicial philosophies or the fact that those differences may lead to differences in our interpretations of the law. Even if this were not so obvious from our opinions, I believe that it would be our duty to share our respective visions of the law with the public. The public should know what approach we as individuals take from the bench; it should be aware that we are not carbon copies of each other; and it should be aware that some decisions are indeed influenced by the philosophies and values that judges bring to the bench.

Further, to impugn the practice of extrajudicial writing is to put a premium on the appearance of impartiality, when impartiality in fact is somewhat of a myth. From this perspective, extrajudicial writing should be wholly allowed; it poses no problems for recusal and bias.

\section{$B$ Conclusions on the Legal Realist Argument}

The author accepts that common law judging is creative and provides scope for judges to be flexible in the application of legal rules. In particular, judges are able to consider what the interests of justice demand in a particular case. Thomas argues that notions of justice "infect the decision-making

221 Brian Z Tamanaha Beyond The Formalist-Realist Divide: The Role of Politics in Judging (Princeton University Press, United States of America, 2010) at 79.

222 Cardozo, above n 214, at 12 .

223 Elias, above n 6, at [33].

224 Judge on the United States Court of Appeals for the Ninth Circuit.

225 Stephen Reinhardt "Judicial Speech and the Open Judiciary" (1995) 28 Loy LA L Rev 805 at 809. 
process" and "may be decisive" when judges weigh competing interests. ${ }^{226}$ Likewise, it is not disputed that judges have their own personal opinions on matters of legal doctrine - publicly expressed or not, these opinions nonetheless exist.

The law on apparent bias and recusal, as it presently stands, does not make provision for this. Elias CJ and Lord Neuberger MR accept the law as it is but note that its operation is perplexing. ${ }^{227}$ Both see a tension in requiring a judge to recuse him or herself because of extrajudicial writing, but simultaneously allowing a judge to sit where there is no writing, but the opinion still held. Elias CJ observed she was "not sure what signal this sends out". ${ }^{228}$ Lord Neuberger went as far as to say that the status quo "seems to value justice being seen to be done above justice actually being done". ${ }^{229}$ These concerns are valid and do expose a difficult area of the law.

Perhaps the somewhat artificial focus on the appearance of impartiality can be justified by the value it is seeking to protect, that being public confidence in the judiciary. If there were doubts about a judge's impartiality and nothing was done to alleviate this, public confidence in the judiciary would be undermined. This would impinge on the effective functioning of the judicial system to the detriment of all. For this reason, the focus on the appearance of impartiality is explicable, although it sits somewhat uncomfortably with impartiality in fact.

\section{CONCLUSION}

The purpose of this article was to analyse the problems extrajudicial academic speech may create. This sort of writing and speaking can cause a judge's impartiality to be questioned. As a consequence, the apparent bias test from Saxmere may be satisfied and the judge may have to recuse or face his or her decision being challenged for bias. This problem could arise in respect of two issues. First, a judge may be biased on a legal matter relevant to the case. The example here is Hoekstra, where bias arose in relation to Lord McCluskey's extrajudicial statements on the European Convention. Secondly, a judge may indicate bias towards some aspect of the facts of a case that later arises before him or her. For example, in Locabail, a personal injury case, the Recorder was found to be biased against the defendants (insurers) and towards the claimant. In New Zealand, this issue arose in the context of Kim Dotcom's extradition hearing, when Judge Harvey appeared biased against the United States in the context of copyright law.

The current approach to this problem, found in judicial conduct codes and case law, is that judges are free to express opinions on legal issues outside of judgments in written publications and speeches.

226 EW Thomas The Judicial Process: Realism, Pragmatism, Practical Reasoning and Principles (Cambridge University Press, New York, 2005) at 275.

227 Neuberger, above n 208, at [23]; and Elias, above n 6, at [33].

228 Elias, above n 6, at [33].

229 Lord Neuberger, above n 208, at [23]. 
However, if the tone and language used are intemperate, the Saxmere test for apparent bias may be satisfied and the judge will need to recuse him or herself.

The remainder of the article analysed whether this is the correct approach. Any approach must navigate between two concerns: protecting judicial free speech, and ensuring the effective and efficient functioning of the legal system. These goals are at odds with each other and the line must be drawn somewhere between them. The status quo achieves an appropriate balance, recognising free speech but also upholding the integrity of the justice system by protecting judicial impartiality. The threshold for recusal is high enough to preclude problems such as litigants bringing hollow bias claims. In this context, a policy of judicial silence is not only unnecessary, but also undesirable. It denies judges the right to express their opinions and robs society of an invaluable educative resource.

The number of extrajudicial articles published in New Zealand law reviews demonstrates there is only a small scope for bias and recusal problems to occur. This suggests adopting a drastic approach of judicial silence is wholly unnecessary. Despite this, the incident with Judge Harvey illustrates that the risk of bias and recusal always exists, even when a judge is quite innocuously speaking at a conference. The media backlash following this incident led to the impartiality of the judiciary being brought into question. This is something to be avoided for the reasons outlined in this article. In order to achieve this, it is important that judges are alert to the concerns associated with extrajudicial speech and that judges tailor their writing and speaking so that bias and recusal problems are not created. 
IX APPENDIX 1: NUMBER OF ARTICLES PUBLISHED BY JUDGES IN NEW ZEALAND LAW REVIEWS 2004-2014

\begin{tabular}{|c|c|c|c|c|c|c|c|c|c|c|c|c|c|}
\hline & \multicolumn{9}{|c|}{ Number of Articles Published by Judges } \\
\hline \begin{tabular}{c} 
Journal \\
\hline $\begin{array}{c}\text { Auckland University } \\
\text { Law Review }\end{array}$
\end{tabular} & - & 0 & 1 & 0 & 0 & 0 & 0 & 0 & 0 & 0 & 0 & 1 \\
\hline $\begin{array}{c}\text { Canterbury Law } \\
\text { Review }\end{array}$ & - & - & 0 & 3 & 0 & 1 & 0 & 0 & 0 & 0 & 1 & 5 \\
\hline Māori Law Review & 2 & 1 & 0 & 0 & 0 & 0 & 0 & 0 & 0 & 0 & 0 & 3 \\
\hline $\begin{array}{c}\text { New Zealand } \\
\text { Intellectual Property } \\
\text { Law Journal }\end{array}$ & 0 & 0 & 0 & 0 & 0 & 0 & 0 & 0 & 0 & 0 & 0 & 0 \\
\hline $\begin{array}{c}\text { New Zealand Journal } \\
\text { of Environment Law }\end{array}$ & 0 & 0 & 0 & 0 & 0 & 0 & 0 & 0 & 0 & 0 & 0 & 0 \\
\hline $\begin{array}{c}\text { New Zealand Journal } \\
\text { of Family Law }\end{array}$ & 0 & 1 & 3 & 2 & 2 & 5 & 1 & 5 & 3 & 4 & 3 & 29 \\
\hline $\begin{array}{c}\text { New Zealand Journal } \\
\text { of Public and } \\
\text { International Law }\end{array}$ & - & 0 & 1 & 0 & 0 & 0 & 2 & 0 & 0 & 0 & 1 & 4 \\
\hline $\begin{array}{c}\text { New Zealand Law } \\
\text { Review }\end{array}$ & 2 & 0 & 0 & 0 & 1 & 0 & 1 & 1 & 0 & 0 & 0 & 5 \\
\hline $\begin{array}{c}\text { New Zealand } \\
\text { Universities Law } \\
\text { Review }\end{array}$ & 0 & 0 & 0 & 1 & 0 & 0 & 0 & 0 & 1 & - & - & 2 \\
\hline Otago Law Review & - & 0 & 0 & 0 & 0 & 0 & 0 & 1 & 0 & 1 & 1 & 3 \\
\hline $\begin{array}{c}\text { Victoria University } \\
\text { Law Review }\end{array}$ & 0 & 0 & 1 & 1 & 2 & 3 & 1 & 0 & 0 & 0 & 0 & 8 \\
\hline Waikato Law Review & 0 & 0 & 0 & 1 & 1 & 1 & 1 & 1 & 1 & 3 & 1 & 10 \\
\hline \begin{tabular}{c} 
Total \\
\hline
\end{tabular} & 4 & 2 & 6 & 8 & 6 & 10 & 6 & 8 & 5 & 8 & 7 & 70 \\
\hline
\end{tabular}

A "-" has been used where the volume was unavailable. 
X APPENDIX 2: NUMBER OF ARTICLES PUBLISHED BY JUDGES 2004-2014, BY COURT

A Table 2.1: Judicial Publications, According to Court

\begin{tabular}{|c|c|c|}
\hline Judge & Court* & Number of Articles \\
\hline Sian Elias & Supreme Court & 12 \\
\hline Peter Blanchard & Supreme Court & 3 \\
\hline William Young & Supreme Court & 1 \\
\hline Grant Hammond & Court of Appeal & 2 \\
\hline Susan Glazebrook & Court of Appeal & 4 \\
\hline Noel Anderson & Court of Appeal & 1 \\
\hline Robert Chambers & Court of Appeal & 1 \\
\hline David Baragwanath & Court of Appeal & 1 \\
\hline Stephen Kós & High Court & 1 \\
\hline Graham Pankhurst & High Court & 1 \\
\hline John Priestly & High Court & 1 \\
\hline Paul Heath & High Court & 2 \\
\hline Eddie Durie & High Court & 1 \\
\hline John Hansen & High Court & 1 \\
\hline Joseph Williams & High Court & 1 \\
\hline David Harvey & District Court & 1 \\
\hline Anna-Marie Skellern & District Court & 1 \\
\hline Peter Spiller & District Court & 1 \\
\hline AP Walsh & District Court & 1 \\
\hline Jan Doogue & District Court and Family Court & 3 \\
\hline Peter Boshier & Family Court & 20 \\
\hline Paul von Dadelszen & Family Court & 3 \\
\hline Dale Clarkson & Family Court & 2 \\
\hline Ian Mill & Family Court & 1 \\
\hline Annis E Somerville & Family Court & 1 \\
\hline Craig Coxhead & Maori Land Court & 2 \\
\hline Andrew Becroft & Youth Court & 1 \\
\hline
\end{tabular}

*As determined at the date the article was published. 
B Table 2.2: Summary of Judicial Publications, According to Court

\begin{tabular}{|l|l|l|}
\hline Court & Number of Publications & Percentage of Total Publications \\
\hline Supreme Court & 16 & $23 \%$ \\
\hline Court of Appeal & 9 & $13 \%$ \\
\hline High Court & 8 & $12 \%$ \\
\hline District Court & 5 & $7 \%$ \\
\hline Family Court & 29 & $41 \%$ \\
\hline Māori Land Court & 2 & $3 \%$ \\
\hline Youth Court & 1 & $1 \%$ \\
\hline
\end{tabular}

C Table 2.3: Summary of Judicial Publications of the Non-Specialist Courts

\begin{tabular}{|l|l|l|}
\hline Court & Number of Publications & Percentage of Total Publications \\
\hline Supreme Court & 16 & $42 \%$ \\
\hline Court of Appeal & 9 & $24 \%$ \\
\hline High Court & 8 & $21 \%$ \\
\hline District Court & 5 & $13 \%$ \\
\hline
\end{tabular}


XI APPENDIX 3: NUMBER OF ARTICLES PUBLISHED BY JUDGES 2004-2014, BY AUTHOR

\begin{tabular}{|c|c|c|}
\hline Judge & Court & Number of Articles \\
\hline Peter Boshier & Family Court & 20 \\
\hline Sian Elias & Supreme Court & 12 \\
\hline Susan Glazebrook & Court of Appeal & 4 \\
\hline Peter Blanchard & Supreme Court & 3 \\
\hline Jan Doogue & District Court and Family Court & 3 \\
\hline Paul von Dadelszen & Family Court & 3 \\
\hline Grant Hammond & Court of Appeal & 2 \\
\hline Paul Heath & High Court & 2 \\
\hline Dale Clarkson & Family Court & 2 \\
\hline Craig Coxhead & Māori Land Court & 2 \\
\hline William Young & Supreme Court & 1 \\
\hline Noel Anderson & Court of Appeal & 1 \\
\hline Robert Chambers & Court of Appeal & 1 \\
\hline David Baragwanath & Court of Appeal & 1 \\
\hline Stephen Kós & High Court & 1 \\
\hline Graham Pankhurst & High Court & 1 \\
\hline John Priestly & High Court & 1 \\
\hline Eddie Durie & High Court & 1 \\
\hline John Hansen & High Court & 1 \\
\hline Joseph Williams & High Court & 1 \\
\hline David Harvey & District Court & 1 \\
\hline Anna-Marie Skellern & District Court & 1 \\
\hline Peter Spiller & District Court & 1 \\
\hline
\end{tabular}




\begin{tabular}{|l|l|c|}
\hline Judge & Court & Number of Articles \\
\hline AP Walsh & District Court & 1 \\
\hline Ian Mill & Family Court & 1 \\
\hline Annis E Somerville & Family Court & 1 \\
\hline Andrew Becroft & Youth Court & 1 \\
\hline
\end{tabular}

XII APPENDIX 4: NUMBER OF ARTICLES PUBLISHED BY JUDGES 2004-2014, BY CATEGORY

\begin{tabular}{|l|l|l|}
\hline Category & Number of Publications & Percentage of Total Publications \\
\hline Substantive Legal Topics & 25 & $36 \%$ \\
\hline Procedural Topics & 18 & $26 \%$ \\
\hline Historical or Biographical Topics & 5 & $7 \%$ \\
\hline Other Topics & 22 & $31 \%$ \\
\hline
\end{tabular}

